Формування математичної компетентності майбутніх учителів початкової школи в дослідницькій діяльності

УДК 378.14:373.3

\title{
ФОРМУВАННЯ МАТЕМАТИЧНОЇ КОМПЕТЕНТНОСТІ МАЙБУТНІХ УЧИТЕЛІВ ПОЧАТКОВОЇ ШКОЛИ В ДОСЛІДНИЦЬКІЙ ДІЯЛЬНОСТІ
}

\author{
Олександр Кошелєв \\ кандидат педагогічних наук, доцент \\ ДВНЗ «Донбаський державний педагогічний університет» \\ м. Слов'янськ, Україна \\ ORCID ID 0000-0003-2576-3381 \\ alleko2005@gmail.com
}

\begin{abstract}
Анотація. Статтю присвячено актуальній проблемі підвищення якості фахової підготовки майбутнього вчителя початкової школи в контексті реформування освіти України і розбудови Нової української школи. Зокрема, автор зупиняється на методичних аспектах формування фахової математичної компетентності студентів засобами дослідницької діяльності. Здійснено теоретичний аналіз поняття «математична компетентність», і визначено iї як складову фахової компетентності майбутнього вчителя початкової школи. Запропоновано власний досвід організації дослідницької діяльності, який передбачає індивідуальну (підготовка рефератів, повідомлень, доповідей для виступу на лекційних, семінарських i практичних заняттях); групову (студентські наукові співтовариства, проблемні групи, наукові семінари) і масову (асамблеї, конгреси, конференції, симпозіуми, форуми) формаи.
\end{abstract}

Ключові слова: професійна підготовка; математична компетентність; проект; конференція; майбутні вчителі початкової школи.

Постановка проблеми в загальному вигляді. Роль освіти на сучасному етапі розвитку України визначається завданнями ії переходу до демократичного і правової держави, до ринкової економіки, необхідністю подолання небезпеки відставання країни від світових тенденцій економічного і соціального розвитку. У сучасному світі значення освіти як найважливішого чинника формування нової якості економіки і суспільства збільшується разом зі зростанням впливу людського капіталу. Українська система вищої освіти здатна конкурувати із системами освіти передових країн. При цьому необхідні широка підтримка проведеної освітньої політики 3 боку громадськості, відновлення відповідальності й активної ролі держави в цій сфері, глибока і всебічна модернізація освіти з виділенням необхідних для цього ресурсів і створенням механізмів їх ефективного використання.

Соціально-економічні та політичні зміни, що відбуваються в сучасному суспільстві, вимагають кардинальних перетворень у всіх сферах, в тому числі і в сфері освіти. Як основа модернізації сучасної вищої освіти і вдосконалення підготовки фахівців у різних галузях розглядається компетентнісний підхід, 3 позицій якого результатом освітньої діяльності стає формування компетентного фахівця. 
Формування математичної компетентності майбутніх учителів початкової школи в дослідницькій діяльності

Щодо вищої педагогічної освіти цей підхід означає ï спрямованість на підготовку компетентного вчителя. У таких умовах особливої актуальності набуває проблема підготовки майбутніх учителів початкових класів, які в силу багатопрофільності своєї педагогічної діяльності покликані закладати основи загальної освіченості молодших школярів. Значимість цього рівня освіти в розвитку особистості учнів початкової школи обумовлює необхідність підготовки вчителя до компетентного здійснення освітньої діяльності різних напрямків (з української мови, математики, природознавства тощо) [2].

Аналіз останніх досліджень і публікацій. Аналіз психолого-педагогічної літератури дозволив нам з'ясувати, що математична підготовка є складовою частиною професійної підготовки майбутнього вчителя, іiі мета визначається 3 урахуванням мети професійної підготовки, в якості якої на основі компетентнісного підходу виступає формування компетентного фахівця педагога. Таким чином, одним із головних завдань математичної підготовки майбутніх вчителів початкових класів $\epsilon$ формування у них математичної компетентності.

Для дослідження природи протікання процесу формування математичної компетентності у майбутніх вчителів початкових класів та можливостей педагогічного впливу на здійснення даного процесу нам треба було уточнити основні поняття нашого дослідження - «математична компетентність вчителя початкових класів »і« формування математичної компетентності у майбутніх вчителів початкових класів».

Аналіз поняття «компетентність» дозволив виявити різноманітність і різноплановість трактувань, які свідчать про складність і багатогранність даного феномена, його відносної новизни в педагогічній науці і відмінності наукових підходів, на які спираються вчені при його визначенні.

При визначенні поняття «математична компетентність вчителя початкових класів» ми враховували дисертаційні дослідження Т. Долматова, Г. Ковальової, Е. Красновського, Л. Краснокутської, К. Краснянської, Н. Ходирєвої.

Поняття «компетенція» та «компетентність» були предметом наукових досліджень найвідоміших російських та українських учених-педагогів В. Байденка, Н. Бібік, І. Зимньої, Н. Кузьміної, А. Маркової, О. Овчарук, О. Пометун, А. Хуторського і становлять основу досліджень цих явищ, дають змогу визначити аналізовані терміни як динамічні поняття. Різні аспекти математичної компетентності фахівців різного профілю досліджували: О. Бєляніна, Л. Іляшенко, Я. Стельмах, а учнів загальноосвітніх шкіл С. Раков, I. Зіненко та інші науковці.

У педагогічній науці поняття «математична компетентність» розглядається по-різному залежно від контексту розв'язуваних дослідниками наукових завдань:

- I. Зіненко розглядає іï як якість особистості, що поєднує в собі математичну грамотність та досвід самостійної математичної діяльності. 
Формування математичної компетентності майбутніх учителів початкової школи в дослідницькій діяльності

Математична компетентність має такі структурні компоненти: мотиваційноціннісний, когнітивний, операційно-технологічний та рефлексивний [5];

- Л. Кудрявцев визначає іiі як інтегративну особистісну якість, засновану на сукупності фундаментальних математичних знань, практичних умінь i навичок, що свідчать про готовність і здатність студента здійснювати математичну діяльність [6];

- згідно з визначенням PISA, це поєднання математичних знань, умінь, досвіду та здібностей людини, які забезпечують успішне розв'язання різноманітних проблем, що потребують застосування математики. При цьому мають на увазі не конкретні математичні вміння, а більш загальні уміння, що включають математичне мислення, математичну аргументацію, постановку та розв'язання математичної проблеми, математичне моделювання, використання різних математичних мов, інформаційних технологій, комунікативні вміння [7, с. 47];

- О. Петрова характеризує математичну компетентність як цілісне утворення особистості, що відображує готовність до вивчення дисциплін, які вимагають математичної підготовки, а також здатність використовувати свої математичні знання для розв'язання різного роду практичних i теоретичних проблем і задач, які зустрічаються у своїй професійній діяльності [8];

- С. Раков описує іiі як уміння бачити та застосовувати математику в реальному житті, розуміти зміст і метод математичного моделювання, уміння будувати математичну модель, досліджувати іiі методами математики, інтерпретувати отримані результати, оцінювати похибку обчислень [9, с. 15]

- Н. Ходирєва визначає математичну компетентність як системну властивість особистості суб'єкта, що характеризує його глибоку обізнаність в предметній області знань, особистісний досвід суб'єкта, націленого на перспективність у роботі, відкритого до динамічного збагачення, здатного досягати значущих результатів і якості в математичній діяльності $[10$, с. 3].

Математичну компетентність вчителя молодшої школи ми розглядаємо як складову його фахової компетентності. Фахова компетентність вчителя - це здатність вчителя ефективно здійснювати педагогічну діяльність, педагогічне спілкування, досягати необхідних результатів в навчанні і вихованості учнів. При цьому «компетентність учителя» передбачає наявність фахових знань та умінь, з одного боку, і фахових позицій, переконань - з іншого. Психологічною складовою фахової компетентності $є$ усвідомлення вчителем необхідності підвищення своєї загальнолюдської і фахової культури й ретельної організації спілкування як основи професійної діяльності. Динаміка розвитку фахової компетентності вчителя визначається зміною репродуктивного виконання дій i операцій творчими та гармонійними компонентами професійної діяльності.

Формулювання цілей статті. Мета статті полягає у визначенні ролі дослідницької діяльності у формуванні математичної компетентності майбутніх учителів початкової школи і висвітленні власного досвіду роботи в цьому 
Формування математичної компетентності майбутніх учителів початкової школи в дослідницькій діяльності

напрямі зі студентами спеціальності 013 Початкова освіта ДВНЗ «Донбаський державний педагогічний університет».

Теоретичні основи дослідження. Вивчення математичної компетентності майбутніх учителів початкової школи та загальних тенденцій ії формування має нормативно-правове підгрунтя: Закони України «Про освіту», «Про вищу освіту», професійний стандарт «Вчитель початкових класів закладу загальної середньої освіти». Важливі теоретичні підвалини дослідження складають зарубіжні й вітчизняні концепції, сучасні стратегії, проекти й ініціативи в галузі професійної освіти, наукові розвідки з питань фахової підготовки майбутніх учителів початкової школи (О. Бігич, Л. Гаврілової, Л. Коваль, О. Савченко, С. Стрілець, І. Хижняк тощо).

Результати дослідження. Основними критеріями сформованості фахової компетентності $\epsilon$ : продуктивність виконання фахових завдань; наявність у професійній свідомості усталених знань, які окреслюють параметри фахової діяльності; здатність до кваліфікованого виконання усіх видів фахової діяльності; уміння створювати оптимальне інформаційне, забезпечення вирішення фахових проблем; володіння формами та методами навчання; високий рівень мотивації саморозвитку фахівця.

Рівень фахової компетентності вчителя математики в молодшій школі пов'язаний з усіма сферами його особистості й залежить від педагогічного потенціалу та бажання подальшого самовдосконалення, які є виразниками його професійного становлення. Лише за наявності базових педагогічних знань, умінь у поєднанні з розвиненою здатністю педагога активно мислити, творити, діяти i бажанням домагатися поставленої мети, він може вийти на підвищення власного рівня методичної діяльності. 3 огляду на це математична компетентність учителя початкових класів нами розуміється як інтегративна характеристика особистості, що включає сукупність мотиваційно-оціночного, когнітивно-орієнтовного та операціонально-технологічного компонентів, що забезпечує досягнення високих результатів в процесі викладання математики в початковій школі.

Спираючись на дослідження з означеної проблеми, з огляду на сутність і структуру поняття «математична компетентність учителя початкових класів», ми розглядаємо формування математичної компетентності у майбутніх вчителів початкових класів як цілісний педагогічний процес, заснований на принципах цілеспрямованості, інтегративності, безперервності і послідовності, варіативності, професійно-педагогічного самовдосконалення, функціональної повноти, універсальності математичної освіти, єдності фундаментальної i прикладної математичної підготовки і спрямований на оволодіння майбутніми учителями цілісної динамічної базою загальнопедагогічних, методичних i спеціальних (предметних) знань, умінь і розвиток позитивної мотивації навчально-пізнавальної діяльності та інтересу до викладання математики в початковій школі. 
Формування математичної компетентності майбутніх учителів початкової школи в дослідницькій діяльності

Процес формування математичної компетентності у майбутніх вчителів початкових класів пов'язаний з різними аспектами, в тому числі і з мотивацією навчально-пізнавальної діяльності, участю студентів в діяльності 3 розвитку математичної компетентності, інтересом майбутнього вчителя до педагогічної діяльності з викладання математики в початкових класах, а також самооцінкою професійної підготовки. Перераховані аспекти математичної компетентності у майбутніх вчителів початкових класів в сукупності представляють складну і багатоаспектну проблему, що знайшла віддзеркалення в численних дослідженнях, де виділяються різні умови, що сприяють даному процесу: забезпечення науково регульованого єдності теоретичної i практичної підготовки (І. Кобиляцький), розвиток мотивів пізнавально-професійної діяльності (В. Сластьонін), формування професійно значущих особистісних якостей педагога (І. Зимня, І. Ісаєв, С. Холостова).

Розвиток позитивної мотивації студентів до викладання математики в початковій школі в нашому дослідженні можливо шляхом включення їх в дослідницьку діяльність, що дозволяє змоделювати проблемні ситуації, що виникають в реальній практиці викладання математики.

Робота здійснювалася в декількох напрямках:

1. Активізація дослідницької діяльності майбутніх педагогів у індивідуальних формах дослідницької діяльності: підготовка рефератів, повідомлень, доповідей для виступу на лекційних, семінарських і практичних заняттях. В рамках даного напрямку нашої роботи студенти займалися написанням статей з проблем математики і методики іï викладання в збірники студентських робіт. На 4-тому курсі майбутні педагоги виконували курсові роботи, тематика яких формувалася 3 урахуванням змісту даного напрямку нашого дослідження. На 5-тому курсі майбутні педагоги продовжували роботу вже при виконанні випускних кваліфікаційних робіт.

2. Організація групових форм дослідницької діяльності студентів знайшла відображення в діяльності студентських наукових товариств, проблемних груп, наукових семінарів, предметом дослідження яких стали різні питання математики та методики ії викладання.

3. Залучення майбутніх педагогів до участі в масових формах дослідницької діяльності асамблеях, конгресах, конференціях, симпозіумах, форумах і т.д. Взяти участь в подібних заходах студенти могли, виступивши 3 доповіддю, опублікувавши статтю або тези, а також виступивши в обговореннях матеріалів на сайті організаторів асамблеї, конгресу, конференції, симпозіуму або форуму. Крім того, розвитку мотивації майбутніх вчителів до педагогічної діяльності 3 викладання математики в початкових класах та підвищення самооцінки рівня професійної підготовки сприяли виконання i захист дослідницьких проектів. Робота над проектом передбачала високу ступінь свободи студентів, їм задавалося тільки напрямок для професійного дослідження, а реалізація залежала від вибору і можливостей самих розробників. 
Формування математичної компетентності майбутніх учителів початкової школи в дослідницькій діяльності

Теми дослідницьких проектів студентів формулювалися так, щоб їх виконання сприяло, по-перше, саморозвитку, зокрема і професійному, оскільки суб'єктивність забезпечує основу розвитку особистості, індивідуальності, універсальності майбутнього педагога; по-друге, формування позиції дослідника, забезпечення його активності та вибірковості; по-третє, розвитку позитивної мотивації, яка є пріоритетною для включення майбутнього фахівця в професійну діяльність (наприклад, «Результативність реалізованих в початковій школі програм з математики», «Роль особистості вчителя початкових класів у формуванні математичного творчості молодших школярів», «Складання портфоліо вчителя-професіонала», «Портрет сучасного вчителя початкових класів », «Наукова організація праці вчителя початкових класів» тощо).

Процес розробки дослідницького проекту передбачав такі етапи:

1. Збір даних і аналіз матеріалу по темі проекту.

2. Побудова на основі вивченого матеріалу інформаційної моделі проекту, яка узгоджувалася з викладачем.

3. Розробка плану.

4. Процес створення проекту.

5. Здійснення поточного контролю викладачем.

6. Апробація і захист проекту за участю експертів.

7. Можливе застосування викладачем цього проекту в процесі навчання, студентами здійснювалася його технічна підтримка.

Виконанням проектів майбутні педагоги займалися як під час самостійної роботи, так і на заняттях дисциплін за вибором «Математична компетентність у майбутніх вчителів початкових класів »,« Варіативні і альтернативні програми 3 математики в початковій школі». спочатку підготовлені проекти обговорювалися на заняттях, а потім були захищені перед великою аудиторією за участю студентів, викладачів, вчителів початкових класів, працівників міського відділу освіти тощо.

На захисті проектів майбутні вчителі початкових класів демонстрували свою точку зору щодо досліджуваної проблеми, відповідали на запитання присутніх в аудиторії фахівців, використовуючи при цьому можливості сучасних інформаційних комунікаційних засобів. Слід зазначити, що в розробці критеріїв оцінки проектів брали участь і самі студенти. Кращі проекти були відправлені на обласний молодіжний конкурс дослідницьких проектів.

Саме така організація методу проектів із застосуванням поточного контролю, планування, наявністю контрольних точок, захисту проектів і його подальшого застосування в професійній діяльності викладача дозволяла максимально мобілізувати можливості студентів і гарантовано приводила до успішних результатів - формування високого рівня математичної компетентності майбутнього вчителя початкових класів.

Особливу роль у підвищенні мотиваційно-оціночної сфери математичної компетентності вчителя ми відводили співпраці з учителями початкових класів 
Формування математичної компетентності майбутніх учителів початкової школи в дослідницькій діяльності

у підготовці дітей до участі в математичних олімпіадах, всеукраїнських конкурсах «Кенгуру» тощо. Студенти активно включалися в роботу, добираючи необхідні для підготовки дітей матеріали, займалися з окремими молодшими школярами, у подальшому разом 3 учителем i дітьми отримували високі результати $(2,3,4$ місця в міській олімпіаді з математики; 1-е місце в конкурсі «Кенгуру»).

Висновки 3 дослідження і перспективи подальших розвідок у цьому напрямі. Таким чином, включення студентів у дослідницьку діяльність може здійснюватися в індивідуальних (підготовка рефератів, повідомлень, доповідей для виступу на лекційних, семінарських i практичних заняттях), групових (студентські наукові співтовариства, проблемні групи, наукові семінари) i масових (асамблеї, конгреси, конференції, симпозіуми, форуми) формах.

Участь у подібних заходах значно посилює інтерес майбутніх учителів до педагогічної діяльності з викладання математики в початкових класах, а також підвищує самооцінку рівня професійної підготовки, зокрема i рівня математичної компетентності.

\section{СПИСОК ВИКОРИСТАНИХ ДЖЕРЕЛ}

1. Глузман, Н. А. (2010). Методико-математична компетентність майбутніх учителів початкових класів. Київ: Вища школа - XXI.

2. Головань, М. С. (2011). Компетенція та компетентність: порівняльний аналіз понять. Педагогічні науки: теорія, історія, інноваційні технології. Науковий журнал. Суми: СумДПУ ім. А С Макаренка, 8(18), 224-234.

3. Головань, М. С. (2014). Математична компетентність: сутність та структура. Науковий вісник Східноєвропейського наиіонального університету, 1, 35-39.

4. Зіненко, I. М. (2009). Визначення структури математичної компетентності учнів старшого шкільного віку. Педагогічні науки: теорія, історія, інноваційні технології, 2, 165174.

5. Красновский, Э. А., Баранова, В. Ю., Ковалева, Г. С. і Кошеленко, Н. Г. (2007). Основные результаты международного исследования образовательных достижений учашихся PISA - 2006. Москва: Центр оценки качества образования ИСМО РАО.

6. Крилова, Т. В. (2014). Психолого-педагогічні аспекти розвитку методичної компетентності вчителя математики. Математика в рідній школі, 4, 2-5.

7. Кудрявцев, Л. Д. (2008). Мысли о современной математике и методике ее преподавания. Москва: Физматлит.

8. Петрова, Е. М. (2012). Понятие «математическая компетентность будущего специалиста технического профиля» в контексте компетентностного подхода. Современные проблемы науки и образования, 1. Получено с www.science-education.ru/101-5504.

9. Раков, С. А. (2005). Математична освіта: компетентнісний підхід 3 використанням IКТ. Харків : Факт.

10. Ходырева, Н. Г. (2001). Становление математической компетентности будущего учителя при подготовке в педагогическом вузе. Педагогические проблемы становления субъектности школьника, студента, педагога в системе непрерывного образования, 3, 67-70. 
Формування математичної компетентності майбутніх учителів початкової школи в дослідницькій діяльності

\title{
ФОРМИРОВАНИЕ МАТЕМАТИЧЕСКОЙ КОМПЕТЕНТНОСТИ БУДУЩИХ УЧИТЕЛЕЙ НАЧАЛЬНОЙ ШКОЛЫ В ИССЛЕДОВАТЕЛЬСКОЙ ДЕЯТЕЛЬНОСТИ
}

\author{
Александр Кошелев \\ кандидат педагогических наук, доцент \\ ГВУЗ «Донбасский государственный педагогический университет» \\ г. Славянск, Украина \\ ORCID ID 0000-0003-2576-3381 \\ alleko2005@gmail.com
}

\begin{abstract}
Аннотация. Статья посвящена актуальной проблеме повышения качества профессиональной подготовки будущего учителя начальной школы в контексте реформирования образования Украины и развития Новой украинской школы. В частности, автор останавливается на методических аспектах формирования профессиональной математической компетентности студентов средствами исследовательской деятельности. Осуществлен теоретический анализ понятия «математическая компетентность», и определены ее как составляющую профессиональной компетентности будущего учителя начальной школы. Предложен собственный опыт организации исследовательской деятельности, предполагает индивидуальную (подготовка рефератов, сообщений, докладов для выступления на лекционных, семинарских и практических занятиях); групповую (студенческие научные сообщества, проблемные группы, научные семинары) и массовую (ассамблеи, конгрессы, конференции, симпозиумы, форумы) формы.
\end{abstract}

Ключевые слова: профессиональная подготовка; математическая компетентность; проект; конференция; будущие учителя начальной школы.

\section{DEVELOPING MATHEMATIC COMPETENCE OF FUTURE PRIMARY SCHOOL TEACHERS IN RESEARCH ACTIVITY}

\author{
Oleksandr Kosheliev \\ Candidate of Pedagogical Sciences, Associate Professor \\ SHEE "Donbas State Pedagogical University" \\ Soviansk, Ukraine \\ ORCID ID 0000-0003-2576-3381 \\ alleko2005@gmail.com
}

\begin{abstract}
The article is devoted to the relevant problem of improving the quality of the professional training of the future primary school teachers in the context of reforming education in Ukraine and building a New Ukrainian school. In particular, the author dwells on the methodological aspects of forming students' professional mathematical competence through the research activities. Analysis of psychological and pedagogical literature allowed to find out that mathematical training is an integral part of the professional training of the future teachers, its purpose is determined in accordance to the purpose of vocational training, which, on the basis of a competence approach, is the development of a competent teacher. Thus, one of the main tasks of mathematical training for future primary school teachers is the development of their mathematical competence.
\end{abstract}


Формування математичної компетентності майбутніх учителів початкової школи в дослідницькій діяльності

The aim of the paper is to determine the role of research activities in developing future primary school teachers' mathematical competence and to highlight the author's experience in this direction with the students of the specialty 013 Primary education at Donbas State Pedagogical University.

A theoretical analysis of the concept of "mathematical competence" has been made, and it is defined as a component of the professional competence of the future primary school teachers. The author proposes his own experience of organizing research activities, which involve individual (preparation of abstracts, reports, reports for speaking at lectures, seminars and practical classes); group (student scientific communities, problem groups, scientific seminars) and mass (assemblies, congresses, conferences, symposiums, forums) forms.

Participation in such events greatly enhances the interest of future teachers in pedagogical activities in teaching mathematics in primary school, as well as increases the self-esteem of the level of professional training, in particular, the level of mathematical competence.

Key words: professional training; mathematical competence; project; conference; future teacher of primary school.

\section{REFERENCES (TRANSLATED AND TRANSLITERATED)}

1. Hluzman, N. A. (2010). Methodological and mathematical competence of future teachers of primary school. Kyiv: Vyshcha shkola - XXI.

2. Holovan, M. S. (2011). Competency and competence: comparative analysis of the concepts. Pedahohichni nauky: teoriia, istoriia, innovatsiini tekhnolohii. Naukovyi zhurnal. Sumy: SumDPU im. A.S. Makarenko, 8 (18), 224-234.

3. Holovan, M. S. (2014). Mathematical competence: essence and structure. Naukovyi visnyk Skhidnoievropeiskoho natsionalnoho universytetu, 1, 35-39.

4. Zinenko, I. M. (2009). Determination of the structure of mathematical competence of pupils of senior school age. Pedahohichni nauky teoriia, istoriia, innovatsiini tekholohii, 2, 165-174.

5. Krasnovskyi, E. A., Baranova, V. Yu., Kovaleva, G. S. \& Koshelenko, N. G. (2007). Osnovnye rezultaty mezhdunarodnogo issledovaniya obrazovatelnykh dostizheniy uchashchikhsya PISA - 2006. Moscow: Tsentr otsenki kachestva obrazovaniya ISMO RAO.

6. Krylova, T. V. (2014). Psychological and pedagogical aspects of the development of methodological competence of the teacher of mathematics. Matematyka $v$ ridniy shkoli, 4, 2-5.

7. Kudryavtsev, L. D. (2008). Thoughts about modern mathematics and methods of its teaching. Moscow: Fizmatlit.

8. Petrova, E. M. (2012). The concept of "mathematical competence of a future specialist in the technical field" in the context of a competence approach. Sovremennye problemy nauki I obrazovaniya, 1. Retrieved from www.science-education.ru/101-5504.

9. Rakov, S. A. (2005). Mathematical Education: A Competency Approach Using ICT. Kharkiv: Fakt.

10. Hodyreva, N. G. (2001). Formation of the mathematical competence of the future teacher in preparation at the pedagogical high school. Pedagogicheskie problem stanovleniya subektnosti shkolnika, studenta, pedagoga $v$ sisteme nepreryvnogo obrazovaniya, 3, 67-70.

Матеріали надійшли до редакції 23.11.2018 р. 